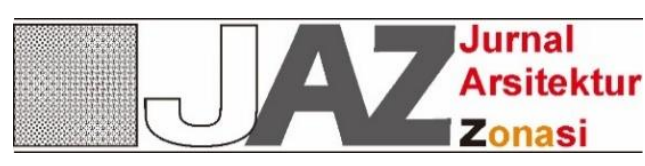

http://ejournal.upi.edu/index.php/jaz - e-mail: jurnal.zonasi@gmail.com dan jurnal_zonasi@upi.edu doi.org/10.17509/jaz.v3i2.25195

\title{
EDUKASI PENDEKATAN VEGETATIF DALAM PENANGANAN BENCANA LONGSOR DI KAMPUNG PLASANSARI
}

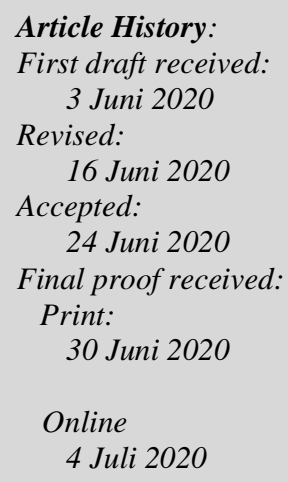

Jurnal Arsitektur ZONASI is indexed and listed in several databases:

SINTA 4 (Arjuna)

GARUDA (Garda Rujukan Digital) Google Scholar

Dimensions

oneSearch

BASE

Member:
Crossref
RJI
APTARI
FJA (Forum Jurna Arsitektur)
IAI
AJPKM

\section{Pendahuluan}

Badan Nasional Penanggulangan Bencana (BNPB) mencatat di tahun 2019 telah terjadi bencana sebanyak 355 kali kejadian tanah longsor di Indonesia. Provinsi Jawa Tengah menjadi wilayah dengan jumlah

\author{
Mussadun $^{1}$ \\ Parfi Khadiyanto ${ }^{2}$ \\ Djoko Suwandono ${ }^{3}$ \\ Endah Kartika Syahri ${ }^{4}$ \\ 1,2,3,4 Urban and Regional Planning, Faculty Engineering, Diponegoro University \\ Jl. Prof. Sudarto No.13, Tembalang, Kec. Tembalang, Kota Semarang, Jawa Tengah 50275 \\ Email: mussadun@gmail.com \\ parfikh@gmail.com \\ dsuwandono@yahoo.com
}

Abstract: Plasansari village is one of the settlements in landslide-prone locations. This is because the geographical conditions in the plasansari village have very steep slopes, types of soil that are easily crossed by water, and high rainfall. The existence of an elite residential area at the top of the village adds to the threat of landslides. This dedication activity aims as education on preventing the threat of landslides by applying a vegetative approach to the plasansari village area. This method is in line with the central government's call to use a vegetative approach in efforts to prevent landslides in a comprehensive manner while empowering the community. The activity was carried out by providing material on the vegetative approach and the geographical condition of the plasansari village. The material provided was the result of the analysis of the community service team in the form of vegetation guidelines for landslide-prone areas in plasansari village. The output of this dedication, the development of the plasansari community's insights on the threat of landslides in the area of residence, and conservation efforts independently by the community using a vegetative approach

Keywords: Community Service, Landslide Disaster, Vegetative Approach

\begin{abstract}
Abstrak: Kampung Plasansari merupakan salah satu permukiman yang berada di lokasi rawan longsor. Hal ini karena kondisi geografi di Kampung Plasansari memiliki kemiringan lahan sangat curam, jenis tanah yang mudah dilewati air, serta curah hujan yang tinggi. Keberadaan kawasan perumahan elit pada bagian atas kampung semakin menambah ancaman terjadinya bencana longsor. Kegiatan pengabdian ini bertujuan sebagai edukasi mengenai pencegahan ancaman bencana longsor dengan menerapkan metode pendekatan vegetatif pada kawasan Kampung Plasansari. Metode ini sejalan dengan imbauan pemerintah pusat untuk menggunakan pendekatan vegetatif dalam upaya pencegahan tanah longsor secara komprehensif sekaligus pemberdayaan kepada masyarakat. Kegiatan dilakukan dengan memberikan materi mengenai pendekatan vegetatif dan kondisi geografis Kampung Plasansari. Materi yang diberikan merupakan hasil analisis tim pengabdian berupa panduan vegetasi untuk kawasan rawan longsor di Kampung Plasansari. Output pengabdian ini, pengembangan wawasan masyarakat Kampung Plasansari mengenai ancaman tanah longsor pada wilayah tempat tinggal, dan upaya konservasi secara mandiri oleh masyarakat dengan menggunakan pendekatan vegetatif.
\end{abstract}

Kata Kunci: Pengabdian Masyarakat, Bencana Longsor, Pendekatan Vegetatif 
kejadian tanah longsor terbanyak di tahun 2019 yaitu 158 kali kejadian. Kota Semarang sebagai ibukota provinsi Jawa Tengah termasuk wilayah yang rawan longsor. Berdasarkan RTRW Kota Semarang tahun 20112031, terdapat 5 wilayah rawan longsor dari 16 Kecamatan di Kota Semarang meliputi Kecamatan Banyumanik. Kecamatan Tembalang, Kecamatan Gunungpati, Kecamatan Gajah Mungkur, dan Kecamatan Semarang Barat.

Pada tahun 2019, tanah longsor terjadi di Kecamatan Banyumanik tepatnya di Kelurahan Srondol Kulon. Longsor disebabkan oleh tingkat kemiringan lereng, bentuk lereng akibat pelapukan material, dan perubahan tutupan vegetasi lereng dan beban berlebih (Nasiah \& Invanni, 2014). Vegetasi memiliki pengaruh terhadap terjadinya bencana longsor, longsor jarang terjadi di daerah dengan kondisi vegetasi yang baik tetapi sering terjadi pada daerah dengan vegetasi yang buruk (Wang \& Peng, 2009). Kelurahan Srondol kulon memiliki tingkat kemiringan lahan yang curam serta perubahan tutupan lahan menjadi kawasan perumahan yang berlebihan menjadi penyebab dari kejadian Tanah longsor di Kelurahan Srondol Kulon.

Kampung Plasansari merupakan salah satu kampung di Kelurahan Srondol Kulon yang pernah mengalami kejadian tanah longsor. Hal ini terjadi akibat perubahan lahan diatas Kampung Plasansari yang telah menjadi kawasan perumahan elit Bukit Indah Regency. Perubahan lahan vegetasi lereng dan beban yang berlebih akibat adanya perumahan menjadi salah satu penyebab dari kejadian tanah longsor. Tutupan vegetasi terutama mempengaruhi stabilitas lereng di daerah curam, dipengaruhi dengan kedalaman dari sistem akarnya (Soewandita, 2018). Dengan semakin baik dan kuatnya sistem perakaran suatu vegetasi maka dapat meminimalisir terjadinya longsor.

Perubahan Vegetasi dapat dirubah atau dikelola dengan baik dan sesuai dengan kaidah konservasi tanah sebagai bentuk mengurangi kejadian Tanah Longsor. Presiden Joko Widodo telah meminta kepada pemerintah daerah untuk mengupayakan konservasi tanah akibat bencana tanah longsor dengan menggunakan pendekatan vegetatif yang terintegrasi dengan masyarakat. Pengaruh vegetasi sendiri tergantung dari jenisnya, apakah berupa tanaman berbatang besar, kecil, atau bahkan hanya berupa semak. Dengan pengelolaan vegetasi pada lahan pertanian berlereng dapat membantu menanggulangi kerusakan lahan akibat longsor. Vegetasi yang beradaptasi baik dapat memberikan kekuatan akar dalam mengikat agregat tanah dan sebagai pilar penahan longsor. Disamping itu vegetasi dengan tanaman buah-buahan dapat memberikan tambahan hasil bagi petani untuk meningkat ekonomi.

Oleh karena itu, upaya konservasi kawasan dapat dilakukan dengan pemulihan lahan dan sekaligus terintegrasi dengan pengabdian kepada masyarakat Kampung Plasansari. Kegiatan ini dilakukan dengan memberikan materi mengenai pendekatan vegetatif dan kondisi geografis Kampung Plasansari. Tujuannya agar masyarakat dapat melakukan upaya konservasi tanah pada lahan lereng di sekitar kawasan permukiman tempat tinggal secara mandiri. Dengan demikian, kegiatan penanaman vegetasi secara mandiri oleh masyarakat dapat mengurangi resiko terjadinya bencana longsor di Kampung Plasansari.

\section{Metode Pengabdian}

Metode pengabdian yang diterapkan dalam lingkup ini adalah sosialisasi secara daring mengenai pendekatan vegetatif untuk kawasan rawan longsor kepada masyarakat Kampung Plasansari. Kegiatan dilakukan secara daring akibat pandemic covid-19 yang mengharuskan untuk jaga jarak atau physical distancing guna mengurangi penyebaran virus. Dalam sosialisasi daring, disampaikan materi mengenai kondisi fisik alam Kampung Plasansari yang merupakan hasil analisis deskripsi dari peta kondisi alam Kota Semarang. Kemudian dari kondisi alam dan potensi bencana yang ada, tim pengabdian mengumpulkan jenisjenis vegetasi yang dapat ditanam untuk mengurangi potensi bencana longsor. Materi tersebut disampaikan kepada masyarakat Kampung Plasansari dengan harapan masyarakat mengetahui mengenai potensi bencana di kawasan tempat tinggal mereka dan dapat melakukan upaya konservasi secara mandiri dengan menggunakan pendekatan vegetatif.

\section{Hasil dan Pembahasan}

\subsection{Kondisi Alam Kampung Plasansari}

Kampung Plasansari merupakan salah satu kampung yang berada di Kelurahan Srondol Kulon, Kecamatan Banyumanik, Kota Semarang. Kampung Plasansari berada di perbatasan antara Kelurahan Srondol Kulon dan Kelurahan Tinjomoyo. Kampung Plasansari merupakan perkampungan yang berada didalam kawasan RW 9 Kelurahan Srondol Kulon. Namun hanya RT 4 dan RT 6 yang terdapat di RW 9 Srondol Kulon yang merupakan Kampung Plasansari. Berikut dibawah ini konstelasi wilayah Kampung Plasansari. 


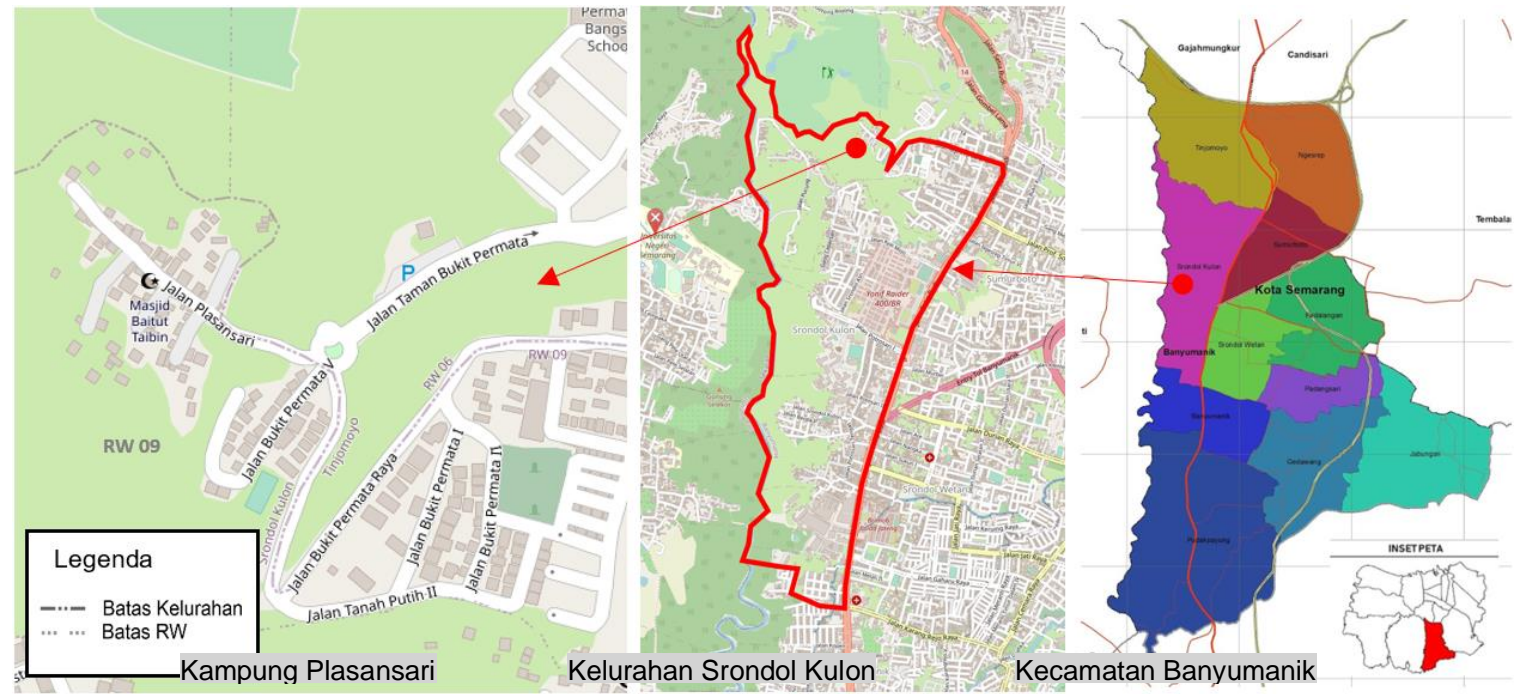

Gambar 3. 1 Konstelasi Wilayah Kampung Plasansari

Kampung Plasansari berada di kelerangan lahan sekitar 25-40\% yang memiliki arti bahwa kemiringan lahan pada kampung berada pada tingkat curam. Kemiringan lahan ini dapat terlihat pada peta kontur di Kampung Plasansari yang memiliki jarak yang sangat dekat seperti pada gambar 4.2. Jarak antar garis kontur pada peta yaitu 5 meter. Pada gambar kerapatan garis kontur sangat berdekatan, hal ini menunjukan Kampung Plasansari berada pada lahan dengan kelerengan yang curam. Kelerengan lahan yang curam sangat rawan terjadi longsor apabila lahan tidak memiliki penahan berupa pohon atau tanaman yang memiliki akar yang kuat. Oleh karena itu sangat diperlukan upaya untuk penjagaan kondisi tanah yang ada di Kampung Plasansari.

Jenis tanah di Kampung Plasansari yaitu tanah latosol coklat kemerahan dan mediteran coklat tua. Tanah latosol memiliki kandungan mineral tanah liat silikat, sehingga tanah latosol ini lengket serta sangat rapuh dan memiliki unsur hara sedang hingga tinggi. Selain itu, tanah latosol mudah dilalui oleh air karena terksturnya yang rapuh. Namun tanah latosol akan mudah kehilangan nutrisi apabila sering dilakukan pelarutan mineralnya (Saptiningsih \& Haryanti, 2015). Jenis tanaman yang cocok pada jenis tanah ini adalah palawija, padi, kelapa karet, dan kopi. Kemudian jenis tanah mediteran coklat tua mampu menyediakan dan menampung banyak air, serta bersifat asam. Tanah mediteran ini merupakan tanah pertanian yang subur pada daerah kapur (MunozRojas et al., 2012). Untuk jenis tanaman yang cocok pada jenis tanah ini adalah palawija, jati, tembakau dan jambu mente.

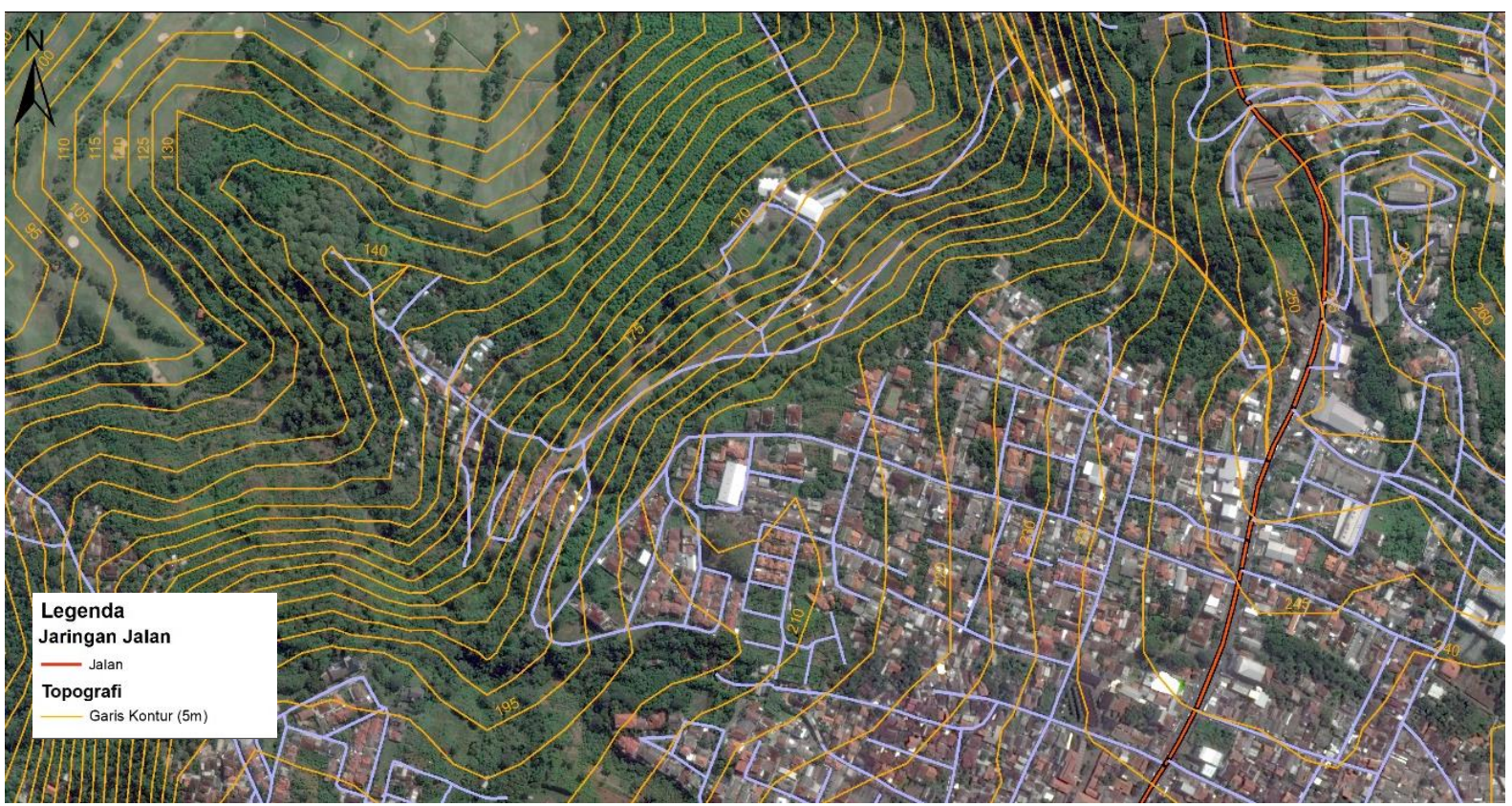

Gambar 3. 2 Peta Topografi Kampung Plasansari 


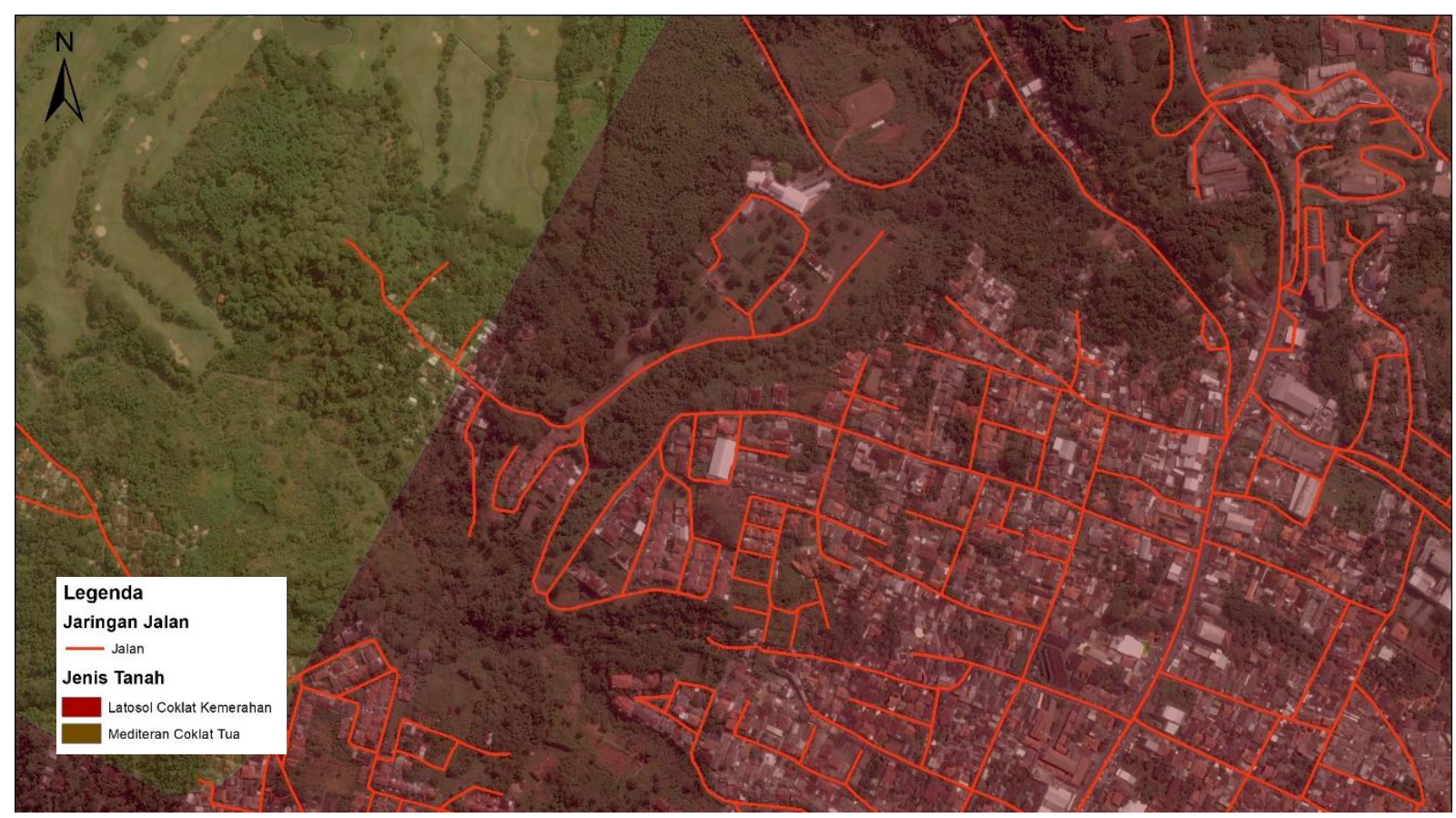

Gambar 3. 3 Peta Jenis Tanah di Kampung Plasansari

Kelurahan Srondol Kulon secara keseluruhan memiliki iklim tropis basah dengan curah hujan 27,7-34,8 $\mathrm{mm} /$ tahun. Angka ini tergolong dalam intensitas curah hujan tinggi. Sehingga apabila tidak didukung dengan lahan yang kuat akan mudah terjadinya bahaya geologi seperti tanah longsor dan banjir (Ichsan, 2015). Namun curah hujan yang tinggi ini sangat menguntungkan untuk pertanian. Hidrogeologi yang ada di Kampung Plasansari, Kelurahan Srondol Kulon merupakan akuifer produktif setempat (Putranto \& Rüde, 2016). Jenis air tanah ini tergolong dangkal dan biasanya ditemukan di lembah-lembah atau pada zona pelapukan.

Kawasan Kampung Plasansari berada dekat dengan bahaya geologi yaitu Sesar Regional Semarang. Keberadaan kampung yang dekat dengan sesar menjadikan kawasan Kelurahan Srondol Kulon sangat rentan terjadi pergerakan tanah tinggi. Hal ini menjadi potensi bahaya geologi yang harus perhatikan dan menjadi salah satu acun dalam pelaksanaan pendekatan vegetatif untuk kawasan rawan longsor. Selain bahaya geologi yang ada, penggunaan lahan di Kampung Plasansari merupakan kawasan permukiman. Meskipun kondisi kemiringan lahan yang curam namun tidak menjadi permasalahan bagi masyarakat dan meraka masih banyak yang bertempat tinggal di kawasan Kampung Plasansari.

\subsection{Kawasan Rawan Longsor di Kampung Plasansari}

Kecamatan banyumanik merupakan salah satu kecamatan yang termasuk daerah rawan bencana. Berdasarkan penelitian Purba, Subiyanto, \& Sasmito (2014), menunjukan bahwa Kecamatan Banyumanik merupakan daerah sangat rawan bencana dengan luasan yang dimiliki 15,106 ha. Sementara itu berdasarkan kelurahan menunjukan bahwa Kelurahan Srondol Kulon berada dalam zona yang cukup rawan dan rawan. Penentuan zona ini dilakukan dengan melihat kondisi fisik alam yang ada pada kawasan pengabdian yaitu Kampung Plasansari.

Kampung Plasansari memiliki jenis tanah latosol coklat kemerahan dan tanah mediteran coklat tua. Kemiringan lahan pada Kampung Plasansari termasuk dalam kemiringan yang curam dengan kelerengan 2540\%. Kemudian curah hujan di Kampung Plasansari yang tergolong tinggi dengan intensitas 27,7-34,8 $\mathrm{mm} /$ tahun. Penggunaan lahan yang saat ini didominasi oleh permukiman, menambah tingkat kerawanan Kampung Plasansari terhadap bencana longsor. Berikut dibawah ini tabel penilaian skor kerawanan bencana longsor di Kampung Plasansari berdasarkan klasifikasi pembobotan menurut Taufik Q, Firdaus dkk (2012) dalam Faizana, Nugraha, dan Yuwono (2015): 
Tabel. 1 Nilai Parameter Ancaman Tanah Longsor di Kampung Plasansari

\begin{tabular}{|l|l|l|}
\hline \multirow{2}{*}{\multicolumn{1}{|c|}{ Parameter }} & \multicolumn{2}{c|}{ Kondisi Kampung Plasansari } \\
\cline { 2 - 3 } & \multicolumn{1}{|c|}{ Jenis } & \multicolumn{1}{c|}{ Nilai Kelas } \\
\hline Kelerengan & $25-40$ & 7 \\
\hline Curah Hujan & $27,7-34,8$ & 10 \\
\hline Penggunaan Lahan & Permukiman & 1,5 \\
\hline Jenis Tanah & $\begin{array}{l}\text { Latosol Coklat Kemerahan dan } \\
\text { Mediteran Coklat Tua }\end{array}$ & 34,5 \\
\hline \multicolumn{2}{|r|}{ Total Nilai Kelas } & \multicolumn{1}{|c|}{3} \\
\hline
\end{tabular}

Sumber: (Faizana et al., 2015)

Berdasarkan total nilai dari parameter ancaman tanah longsor, Kampung Plasansari termasuk dalam kelas ancaman tanah longsor tinggi. Kawasan Kampung Plasansari juga termasuk wilayah dengan pergerakan tanah tinggi dan dilalui oleh sesar regional Kota Semarang. Kemudian posisi kampung plasansari berada di bawah dari kawasan perumahan elit Bukit Indah Regency. Hal ini semakin menambah tingkat kerawanan bencana tanah longsor di Kampung Plasansari.

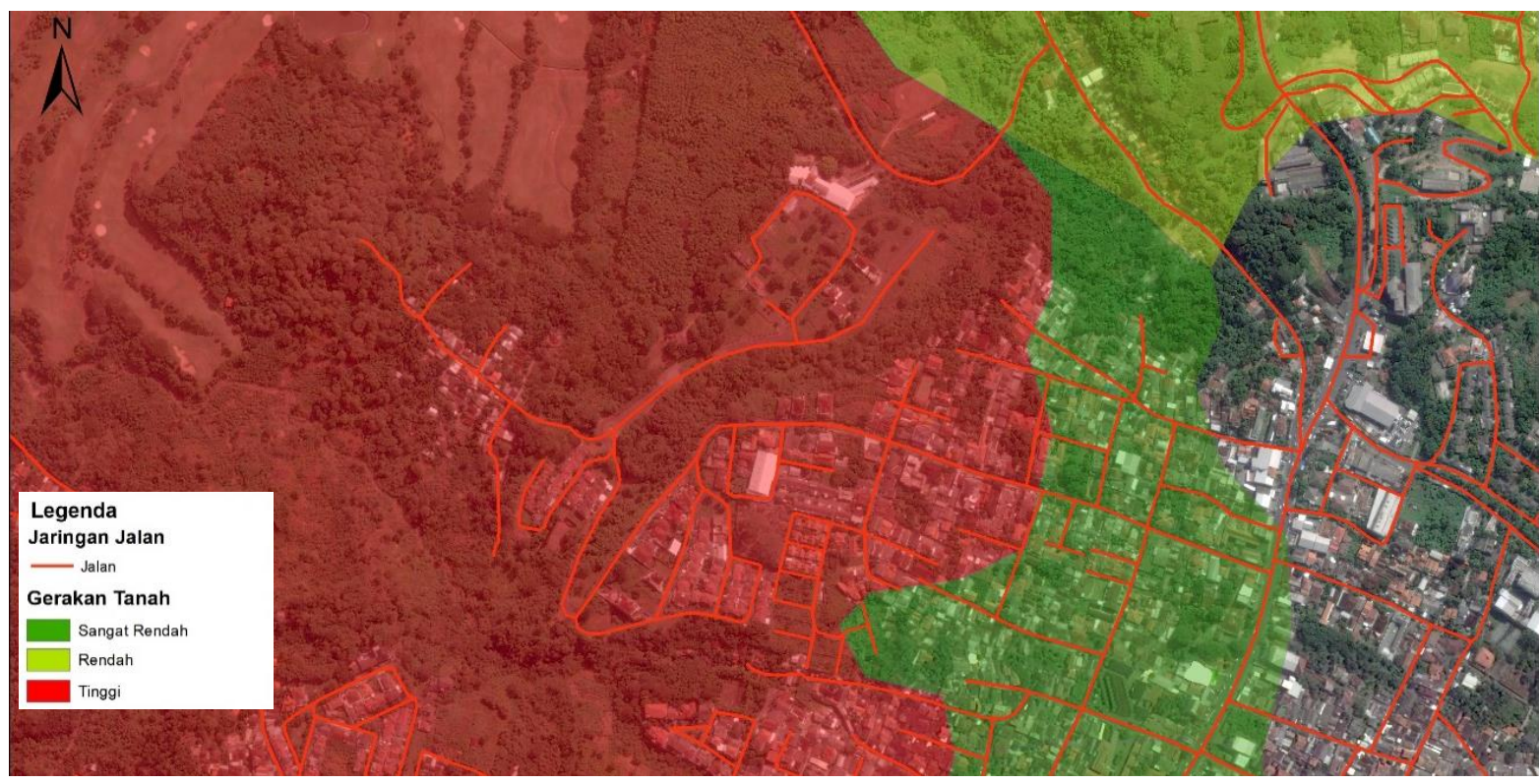

Gambar 4. 4 Peta Gerakan Tanah di Kampung Plasansari

\subsection{Upaya Pencegahan Longsor dengan Pendekatan Vegetasi}

Pendekatan vegetatif merupakan sebuah usaha pengendalian erosi dan pengawetan tanah/air dengan memanfaatkan pengelolaan tanaman untuk menekan terjadinya laju erosi dan pengawetan tanah. Pendekatan ini dapat dilakukan dengan kegiatan berupa penghijauan kembali (reboisasi). Penanaman tanaman penutup lahan, penanaman dalam strip, penanaman mengikuti garis kontur, penanaman bergilir serta pemanfaatan serasah tanaman. Pendekatan vegetatif dapat dijadikan sebagai cara dalam mengurangi ancaman longsor sebab tanaman dapat memelihara kestabilan struktur tanah melalui sistem perakaran dan penutupan lahan. Tanaman dapat meningkatkan infiltrasi dan mencegah erosi serta dapat memiliki nilai ekonomi (Maridi, 2011).

Kampung Plasansari memiliki jenis tanah yang mudah dilalui oleh air. Namun tutupan lahan saat ini didominasi dengan perkerasan fungsi permukiman. Pada saat terjadi hujan dengan intensitas tinggi, air akan masuk kedalam tanah dan apabila tidak terdapat penahan yang cukup kuat dapat mengakibatkan terjadinya tanah longsor. Oleh karena itu, perlu dilakukan upaya penutupan lahan dengan penanaman tanaman yang memiliki akar kuat sehingga tidak mudah terjadi longsor di Kampung Plasansari.

Kampung Plasansari termasuk dalam zona potensi longsor tipe B karena memiliki kemiringan lereng sekitar 25\% sampai dengan $40 \%$. Menurut (Riyanto, 2016) terdapat beberapa tanaman yang dapat dipilih untuk 
upaya pengendalian longsor lahan. Pemilihan jenis tanaman didasarkan vegetasi tanaman keras, zona potensi longsor dan ketinggian tempat tumbuh tanaman terhadap permukaan laut (elevasi). Kampung Plasansari memiliki ketinggian 140 meter hingga 200 meter diatas permukaan laut. Berdasarkan ketinggian tersebut, Kampung Plasansari termasuk dalam zona rawan longsor tipe C. Banyak terdapat jenis tanaman yang dapat ditanam untuk mengurangi potensi bencana longsor berdasarkan ketinggian dan elevasi kawasan, diantaranya: Pilang (Acacia leucophloea), Cempedak (Artocarpus champeden), Sukun (Artocarpus communis), Mimba (Azadirachta indica), Kemiri (Aleuritas mollucana),Jambu Mente (Anacardium occidentale), Aren (Arenga pinnata), Damar (Agathist alba), Bambu (Bambusa sp), Durian (Durio zibethinus) dan berbagai macam tanaman lain sesuai petunjuk dalam buku Rekayasa Vegetatif Untuk Mengurangi Resiko Longsor dari Kementrian Lingkungan Hidup dan Kehutanan.

Kota Semarang memiliki suhu udara sekitar $24^{\circ} \mathrm{C}$ hingga $33^{\circ} \mathrm{C}$, dengan mempertimbangkan suhu udara hanya beberapa tanaman yang sekiranya dapat tumbuh di kawasan Kampung Plasansari. Meskipun Kampung Plasansari berada di Kecamatan Banyumanik yang berada di bagian atas Kota Semarang namun untuk suhu udara tidak jauh berbeda dengan suhu udara di Semarang bagian bawah. Oleh karena itu, berikut ini beberapa tanaman yang dapat ditanam untuk mencegah bencana longsor di Kampung Plasansari:

\section{Tabel 2. Jenis Tanaman Pencegah Longsor di Kampung Plasansari}

\begin{tabular}{|c|c|c|c|}
\hline $\begin{array}{c}\text { Jenis } \\
\text { Tanaman }\end{array}$ & Habitat Tumbuh & Manfaat & Sumber \\
\hline Cempedak & $\begin{array}{l}\text { Tumbuh baik di dataran rendah hingga } 1000 \\
\text { mdpl, suhu } 16-32^{\circ} \mathrm{C} \text {, pada tanah liat berpasir, } \\
\text { tanah gembur dan organic tinggi pH 5-7 }\end{array}$ & $\begin{array}{l}\text { Buahnya dapat dikonsumsi } \\
\text { langsung atau dijadikan } \\
\text { makanan olahan sehingga } \\
\text { memiliki nilai ekonomis. } \\
\end{array}$ & $\begin{array}{l}\text { (Fitmawati, } \\
\text { Andani, \& } \\
\text { Sofiyanti, 2019) }\end{array}$ \\
\hline Sukun & $\begin{array}{l}\text { Tumbuh subur didaerah tropis dengan } \\
\text { ketinggia } 0-650 \text { mdpl. Suhu } 21-35^{\circ} \mathrm{C}\end{array}$ & $\begin{array}{l}\text { Memiliki nilai ekonomis untuk } \\
\text { dijadikan olahan makanan. Akar } \\
\text { tunggang untuk menjaga } \\
\text { kestabilan tanah. }\end{array}$ & $\begin{array}{l}\text { (Risnandar \& } \\
\text { Damaiyanti, } \\
\text { 2018) }\end{array}$ \\
\hline Nangka & $\begin{array}{l}\text { Hampir sama dengan cempedak, namun } \\
\text { tidak tahan terhadap genangan namun harus } \\
\text { cukup air. }\end{array}$ & $\begin{array}{l}\text { Memiliki nilai ekonomis. Akar } \\
\text { tunggang dan dapat menembus } \\
\text { kedalaman } 10-15 \text { meter. }\end{array}$ & $($ ITO, 2013) \\
\hline Durian & $\begin{array}{l}\text { Suhu } 20-30^{\circ} \mathrm{C}, \text { Curah Hujan maksimum } \\
3000-3500 \text { dan minimal } 1500-3000 \\
\mathrm{~mm} / \text { tahun, pH 5-7 membutuhkan kandungan } \\
\text { air tanah dengan kedalaman } 50-150 \mathrm{~cm} \text { dan } \\
150-200 \mathrm{~cm},<800 \mathrm{mdpl}\end{array}$ & $\begin{array}{l}\text { Memiliki perakaran dalam untuk } \\
\text { kestabilan tanah dan memiliki } \\
\text { nilai ekonomis dari buah yang } \\
\text { dihasilkan. }\end{array}$ & $\begin{array}{l}\text { (Tirtawinata, } \\
\text { Santoso, \& } \\
\text { Apriyanti, 2016) }\end{array}$ \\
\hline Lamtoro & $\begin{array}{l}\text { Curah hujan optimal } 800-1500 \mathrm{~mm} \text { pertahun. } \\
\text { Cukup tahan kering Iklim tropis yang } \\
\text { hangat, suhu } 25-30^{\circ} \mathrm{C} \text {, ketingian dibawah } \\
1000 \text { mdpl. }\end{array}$ & $\begin{array}{l}\text { Akarnya dapat menembus kuat } \\
\text { ke dalam tanah dan tidak mudah } \\
\text { tumbang. }\end{array}$ & $\begin{array}{l}\text { (Greenplanet, } \\
\text { 2015) }\end{array}$ \\
\hline Waru & $\begin{array}{l}\text { tumbuh baik di daerah panas dengan curah } \\
\text { hujan } 800 \text { sampai } 2.000 \mathrm{~mm} \text {. Paling baik } \\
\text { ditanah asam hingga alkali 5-8.5 } 800 \mathrm{mdpl}\end{array}$ & $\begin{array}{l}\text { Akar tunggang putih } \\
\text { kekuningan. Tanaman peneduh }\end{array}$ & $\begin{array}{l}\text { (Chrisnanto, } \\
\text { Ismiyati, \& } \\
\text { Medayati, 2014) } \\
\end{array}$ \\
\hline Alpukat & $\begin{array}{l}\text { Tumbuh di daerah tropis dan subtropis yang } \\
\text { banyak curah hujannya. Tanaman buah } \\
\text { berupa pohon kecil dapat tumbuh di dataran } \\
\text { rendah sampai dataran tinggi, yaitu 5-1500 } \\
\text { m dpl. }\end{array}$ & $\begin{array}{l}\text { Memiliki nilai ekonomis dan } \\
\text { memiliki sistem akar dangkal } \\
\text { yang sangat agresif dengan } 60 \% \\
\text { akarnya terletak di atas } 7 \mathrm{~cm} \\
\text { (dalam). }\end{array}$ & $\begin{array}{l}\text { (Dinas Pertanian } \\
\text { D.I. Yogyakarta, } \\
\text { 2000) }\end{array}$ \\
\hline Cengkeh & $\begin{array}{l}\text { tumbuh baik pada daerah yang memiliki } \\
\text { curah hujan sekitar } 2210-3607 \mathrm{~mm} / \text { tahun } \\
\text { serta suhu udara berkisar } 24-39^{\circ} \mathrm{C}\end{array}$ & $\begin{array}{l}\text { Akar tunggang dan sangat jauh } \\
\text { masuk ke dalam tanah, memiliki } \\
\text { nilai ekonomis }\end{array}$ & (Rusnani, 2012) \\
\hline
\end{tabular}

\section{Kesimpulan}

Masyarakat Kampung Plasasanri masih belum menyadari akan bahaya longsor yang mungkin terjadi di daerah tempat tinggalnya. Hampir setiap rumah telah diberi perkerasan pada halamannya berupa semen dan beberapa dengan paving. Namun kondisi tanah yang mudah dilalui air dan pergerakan tanah yang cukup tinggi mengakibatkan tingginya potensi rawan longsor di Kampung Plasansari. Kegiatan Pengabdian kepada masyarakat Kampung Plasansari berlangsung dengan pemberian materi mengenai rawannya lokasi tempat 
tinggal dan edukasi mengenai pendekatan vegetatif sebagai upaya pencegahan. Berdasarkan pengabdian yang telah dilakukan jenis tanaman yang terpilih yaitu tanaman cempedak, nangka, sukun, durian, lamtoro, waru, alpukat dan cengkeh. Jenis tanaman tersebut merupakan tanaman berbuah dan memiliki akar tunggang. Hal ini menjadi jenis yang sesuai di Kampung Plasansari selain memberikan keuntungan untuk perbaikan lahan namun juga memberikan keuntungan secara ekonomi terhadap masyarakat. Dengan dilakukannya pengabdian ini, masyarakat dapat melakukan upaya konservasi dengan penanaman sesuai jenis tanaman yang telah diberikan. Penanaman dapat dilakukan pada kawasan bagian atas perbatasan dengan Perumahan Bukit Indah Regency, pada bagian bawah sekeliling Kampung Plasansari dan pekarangan rumah dengan membuka sedikit perkerasan untuk ruang tanaman.

\section{Ucapan Terima Kasih}

Terima kasih kepada Fakultas Teknik Universitas Diponegoro yang telah membiayai program pengabdian kepada masyarakat ini melalui dana selain APBN Fakultas Teknik RKAT Universitas Diponegoro Tahun Anggaran 2020.

\section{Referensi}

Chrisnanto, E., Ismiyati, N., \& Medayati, B. D. (2014). Waru (Hibiscus tiliaceus). Diambil dari CCRC UGM website: https://ccrc.farmasi.ugm.ac.id/?page_id=227\#

Dinas Pertanian D.I. Yogyakarta. (2000). Alpukat / Avokad. In Budidaya Pertanian.

Faizana, F., Nugraha, A., \& Yuwono, B. (2015). Pemetaan Risiko Bencana Tanah Longsor Kota Semarang. Jurnal Geodesi Undip, 4(1), 223-234.

Fitmawati, F., Andani, V., \& Sofiyanti, N. (2019). Jenis-Jenis Cempedak (Artocarpus champaden Lour.) di Kabupaten Kampar Provinsi Riau. EKOTONIA: Jurnal Penelitian Biologi, Botani, Zoologi dan Mikrobiologi, 3(1), 35-43. https://doi.org/10.33019/ekotonia.v3i1.756

Greenplanet. (2015). Benih Lamtoro. Diambil dari greenplanet website: http://www.greenplanet.co.id/index.php/ind/single?id=140\&category=Benih+Lamtoro\#: :text=Habitat \%3A Lamtoro menyukai iklim tropis, $800-1.500 \mathrm{~mm}$ ) pertahun.

Ichsan, I. (2015). Identifikasi Daerah Rawan Bencana Longsor Lahan Sebagai Upaya Penanggulangan Bencana di Kabupaten Sinjai. Sainsmat: Jurnal Ilmiah Ilmu Pengetahuan Alam, 3(2).

ITO, S. (2013). Keragaman Nangka (Artocarpus heterophyllus) di Pulau Jawa: Ciri- Ciri Morfologi dan Kualitas Buah. Universitas Gadjah Mada.

Maridi. (2011). Pendekatan Vegetatif Dalam Upaya Konservasi Das Bengawan Solo (Studi Kasus di Sub DAS Keduang). Seminar Nasional VIII Pendidikan Biologi, 209-214.

Munoz-Rojas, M., Jordan, A., Zavala, L. M., De La Rosa, D., Abd-Elmabod, S. K., \& Anaya-Romero, M. (2012). Organic Carbon Stocks in Mediterranean soil types under different land uses (Southern Spain). Solid Earth, 3, 375-386. https://doi.org/10.5194/se-3-375-2012

Purba, J. O., Subiyanto, S., \& Sasmito, B. (2014). Pembuatan Peta Zona Rawan Tanah Longsor di Kota Semarang dengan Melakukan Pembobotan Parameter. Jurnal Geodesi Undip, 3(2), 40-52.

Putranto, T., \& Rüde, T. (2016). Hydrogeological model of an urban city in a coastal area, case study: Semarang, Indonesia. Indonesian Journal on Geoscience, 3(1), 17-27.

Risnandar, C., \& Damaiyanti, A. K. (2018). Buah Sukun. Diambil dari jurnalbumi website: https://jurnalbumi.com/knol/buah-sukun/\#: :text=Habitat Tumbuh,1500-3000 mm per tahun.

Riyanto, H. D. (2016). Rekayasa Vegetatif untuk Mengurangi Risiko Longsor. Surakarta: Kementrian Lingkungan Hidup dan Kehutanan.

Rusnani, I. (2012). Pengaruh Pemotongan Akar Tunggang Bengkok Terhadap Pertumbuhan Bibit Cengkeh (Universitas Muhammadiyah Surakarta). https://doi.org/10.1007/978-3-540-71095-0_10277

Saptiningsih, E., \& Haryanti, S. (2015). The Content of Cellulose and Lignin Various Sources of Organic Matter Decomposition in the Soil After the Latosol. Buletin Anatomi dan Fisiologi, 23(2), 34-42. https://doi.org/https://doi.org/10.14710/baf.v23i2.10008

Tirtawinata, M., Santoso, P., \& Apriyanti, L. (2016). Durian: Pengetahuan Dasar Untuk Pecinta Durian. Agriflo. 